\title{
Urgences
}

\section{Suite allemande}

\section{Sigman}

Numéro 20, mai 1988

Appellation contrôlée

URI : https://id.erudit.org/iderudit/025479ar

DOI : https://doi.org/10.7202/025479ar

Aller au sommaire du numéro

Éditeur(s)

Urgences

ISSN

0226-9554 (imprimé)

1927-3924 (numérique)

Découvrir la revue

Citer ce document

Sigman, L. (1988). Suite allemande. Urgences, (20), 41-44.

https://doi.org/10.7202/025479ar

Ce document est protégé par la loi sur le droit d'auteur. L'utilisation des services d'Érudit (y compris la reproduction) est assujettie à sa politique d'utilisation que vous pouvez consulter en ligne.

https://apropos.erudit.org/fr/usagers/politique-dutilisation/
Cet article est diffusé et préservé par Érudit.

Érudit est un consortium interuniversitaire sans but lucratif composé de l’Université de Montréal, l'Université Laval et l'Université du Québec à Montréal. Il a pour mission la promotion et la valorisation de la recherche. https://www.erudit.org/fr/ 


\section{SIGMAN \\ Suite allemande}

Les grandes statues blanches du parc font signe. «Des ombres nous habitent», dit-elle. Comme une révélation rend visible l'image latente, le caché de l'anonymat. Cette femme entend le malaise dans le nom. Radicalement, le pseudonyme veut rompre avec la famille. Il n'est qu'un déguisement pour la mascarade des tensions. Comme une forcenée, cette femme hors du commun rêve un grand rêve devant les livres. 
Parmi le grouillement des êtres, le murmure des fontaines, se glisse une voix intérieure, toute en modulations. *Un penchant prononcé pour la lumière parfumée du jardin», dit-elle. Comme pour se désarmer, se donner une possibilité d'évasion. Cette femme dénoue les tresses de sa chevelure. Elle respire le navrant de l'aube. Alors seulement, elle peut se choisir un nom d'adoption et de coeur. Une sorte de refuge pour orpheline. 
Sous la pluie de novembre, la fragilité des fougères roussies. Du côté allemand de la mémoire, frôler les objets détériorés. «La photo de la grand-mère comme figure du dramex, dit-elle. Cette femme reprend le fil des lettres interceptées, anonymes, amoureuses. Contre la traduction des gutturales et le trafic ferroviaire vers les camps. Elle se voit très bien dans les yeux si gravement noirs, le profil tremblé. 
Au bord de la mer gelée, il y a quelque chose de ténu dans le paysage qui chavire. Une rage sourde et une complicité tacite. Comme s'il s'agissait de mettre en liaison les généalogies tronquées, truquées. «'écris, c'est un travail dément», dit-elle. Mais dans cet échange des noms, l'épreuve laisse enfin des traces durables. 